\title{
Classroom Interaction

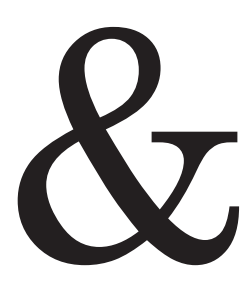 Language
Learning in CLIL contexts
}

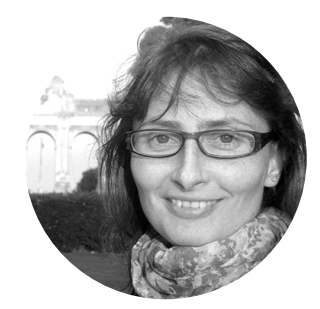

NATALIA EVNITSKAYA

UNIVERSITAT INTERNACIONAL DE CATALUNYA

nevnitskaya@uic.es

T his article provides a comprehensive overview of the key aspects of classroom interaction in L2 and CLIL contexts and its effects on students' academic and language development in such educational settings. It also aims to raise awareness of the role of language and discourse in teaching content and language in CLIL classrooms. More specifically, it discusses how teachers can efficiently enact Classroom Interactional Competence $(\mathrm{CIC}$ ) which is a range of interactional strategies adjusted to the classroom microcontext and which are essential for the correct development of the teaching-learning process. The article presents how teachers can use classroom interaction to guide students in better understanding of subject-specific content, foster the development of students' communicative competence in a foreign language and the integrated learning of content and language as well as promote a more active students' participation in content-rich contexts. Last but not the least, the article discusses the role of the teacher in providing emotional support in the classroom and creating a safe environment where students can develop a positive selfimage through their interactions both with the teacher and the peers.

\section{KEYWORDS:}

CLIL, classroom interaction, IRF (Initiation-Response-Feedback) / IRE (Initiation-Response-Evaluation), interactional guiding / scaffolding strategies, $\mathrm{CIC}$ (Classroom Interactional Competence), face-saving repair strategies

\begin{abstract}
- Ste artículo presenta aspectos clave de la interacción en - el aula en contextos de L2 y AICLE, y de sus efectos sobre el desarrollo académico y lingüístico de los estudiantes. También tiene como objetivo despertar la conciencia del lector sobre el papel de la lengua y del discurso en la enseñanza integrada del contenido y de la lengua extranjera en las aulas AICLE. Más específicamente, se analiza cómo los docentes pueden desplegar de manera eficiente su Competencia Interactiva Escolar - CIE, en forma de estrategias interactivas ajustadas al microcontexto del aula, que son imprescindibles para el correcto desarrollo del proceso de enseñanza-aprendizaje. También se describe cómo los profesores pueden utilizar la interacción en el aula para guiar a los estudiantes hacia una mejor comprensión del contenido específico de la asignatura y fomentar el desarrollo de la competencia comunicativa en la L2, así como promover una participación más activa del alumnado en contextos ricos en contenido. Finalmente, se analiza el papel de los docentes en el apoyo emocional a los estudiantes y en la conversión del aula en un entorno seguro, donde estos puedan desarrollar su imagen en positivo mediante la interacción con el docente y con sus compañeros de clase.
\end{abstract}

\section{PALABRAS CLAVE:}

AICLE, interacción en el aula, IRF (Iniciación o Pregunta-RespuestaRetroalimentación) / IRE (Iniciación o Pregunta-RespuestaEvaluación), estrategias interactivas de guía / andamiaje, CIE (Competencia Interactiva Escolar), estrategias de reparación de la imagen personal. 


\section{Understanding the structure of classroom interaction}

C urrent neo-Vygotskian sociocultural theories on teaching and learning (e.g., Mercer, 2000), including second language learning, propose that students' active participation in classroom interaction, both between teachers and students and among students working in groups, is essential for learning (e.g., Van Lier, 2008). This has led some researchers to argue that there is a 'possibility that educational success and failure may be explained by the quality of educational dialogue, rather than simply in terms of the capability of individual students or the skill of their teachers' (Mercer, 2004: 139; see also Escobar Urmeneta, 2016; Escobar Urmeneta \& Evnitskaya, 2013). Understanding the structure and functions of interaction between teachers and students can therefore give us a better understanding of how the processes of teaching, learning, knowledge construction and meaning-making are enacted in the classroom (e.g., Nikula, Dalton-Puffer \& Llinares, 2013).

In any classroom around the world, whether in the L1 or L2, with children, teenagers or adult learners, we often find that classroom interaction follows a certain interactional pattern which comprises three moves, two performed by the teacher and one performed by the learner. We can clearly observe this pattern in Extract 1 taken from a grade 7 CLIL science classroom in which the teacher and the students study different types of physical adaptations necessary to live in diverse ecosystems:

\section{Extract 1}

1. TEACHER: Ok. And now tell me some physical adaptations about camels.

2. STUDENT 1: ((reads from his notes)) Camel has long eyelashes.

3. TEACHER: Very good ((nods)). Have long eyelashes to keep sand out.

This three-move exchange has come to be known as the IRF (Initiation-Response-Feedback/Follow-up; Sinclair \& Coulthard, 1975) or IRE (Initiation-Response-Evaluation; Mehan, 1979) sequence (see Figure 1).

Figure 1. IRF/IRE sequence

TEACHER: Tell me some physical adaptations about camels.

STUDENT: Camel has long eyelashes.

TEACHER: Very good. Have long eyelashes to keep sand out.
Initiation

Response
This sequence will sound very familiar to anyone who used to be a pupil. This is because, as educational research has discovered, the IRF sequence is the most common and dominant pattern of classroom interaction and teachers' pedagogical discourse in general (Dalton-Puffer, 2007) all over the world. Its omnipresence in classrooms has been widely criticised for reflecting a transmission model of teaching and teacher-centred classrooms because:

- IRF maintains unequal power relations and an unequal distribution of talk time in the classroom since it structures classroom interaction too tightly.

- IRF functions as a powerful tool for teachers to manage their classrooms. By controlling the patterns of interaction teachers can easily manage turn-taking, the length of students' contributions and the topic of conversation. Teachers decide who speaks, when, to whom and for how long in the classroom.
- The predominance of IRF in classroom interaction creates a specific type of interaction, which may become mechanical and monotonous, and if so, less than favourable for learning opportunities.

- IRF severely limits students' talking time by only allowing them to contribute with minimal responses and limits their opportunities to introduce new interactional topics, ask questions or negotiate meaning, thus hindering the development of their communicative and interactional competences. It also offers little opportunity for learners' cognitive development. 
However, research has also shown that the appropriate use of the IRF sequence can bring positive results:

- IRF allows teachers to monitor students' knowledge and understanding, help them to evaluate their current teaching and plan future teaching.

- IRF is necessary for ensuring that the classroom discussion is orderly, and that, as far as possible, everybody contributes and benefits from the knowledge that is being constructed together. By using meaningful and open questions in the I-move to explore learners' views and the F-move to expand on the topic being studied, teachers can also enhance classroom interaction, promote students' participation and help them gain deeper understanding of subjectmatter content.

In any case, IRF-type of explanations are preferable to monologue-style teacher explanations, because with the former learners are invited to co-construct the explanation, thus leading to a higher degree of interaction and involvement in the teaching-learning process. On the other hand, students' contributions provide the teacher with information about their current degree of understanding of subject-specific content, target concepts, etc., thus allowing for the necessary adjustments.

In short, IRF is a type of pedagogical discourse with many properties that are conducive to learning. At the same time, it may also bring about a number of possible threats to the development of high order thinking, communicative and interactional skills. It is up to the knowledgeable teacher to bypass these threats.

\section{Two languages in every classroom: Everyday Language and Academic Language}

in $\mathrm{n}$ the 1980s, researchers, looking at L2 immersion classes where English-speaking students learned school subjects in French first noticed that even after years of schooling in the L2, learners' skills in French in certain areas (e.g., subject-specific writing or speaking) were still lower than those of their L1 French-speaking classmates (Swain \& Johnson, 1997). To explain this phenomenon and find ways to help learners develop their content-related skills in the L2, Cummins (1991) suggested two key dimensions of language proficiency, independently of whether it is in the L2 or L1. The first dimension, Basic Interpersonal Communication Skills (BICS), usually comes into play in highly contextualised, everyday informal interactions which give participants many contextual clues to interpret what is being done and said. By contrast, the second dimension, Cognitive Academic Language Proficiency (CALP), is necessary for context-reduced communication situations, such as when one needs to understand, read, talk or write about abstract and complex academic topics, for example at school. Research shows that in immersion and context- based contexts learners acquire BICS in the L2 rather quickly and can become notably fluent in using everyday L2 within a year or two, or even earlier. CALP, however, might take students many years to understand and use. According to Cummins (1991), this process can take a span of up to seven-eight years and therefore requires teachers' explicit and continuous support and guidance.

There is thus a gap between, on the one hand, students' informal or everyday ways of speaking about the world around them based on their everyday experiences as well as on their own judgment and concerns, and, on the other, academic language, a very different, specialised, highly technical and conceptually challenging way of speaking about the world which they are expected to learn at school. This quote from a blog written by the assistant headmaster of a secondary school in UK clearly spells out the challenges teachers and students face every day:

We believe that the variation between the language of the home and community and the language of school, or as it is more commonly labelled, academic literacy, is at the heart of a great deal of the underachievement of identifiable groups of learners in British schools. [...] It is not possible to make the meanings of academic subjects using the home language of some groups of students. [...]

Less obvious but equally important is the variation in language use between different social groups who are English speakers and the academic language of school subjects. [...] Our view is that the issues faced by underachieving white working class and other native-English speaking groups are also language-related."

\section{(Retrieved from https://whatslanguagedoinghere.wordpress. com/2013/03/16/blog-1-theory/)}

To breach the learners' gap between these two ways of speaking in the classroom, teachers should explicitly guide learners in their acquisition of academic language from a very early educational stage, always adjusting it to the learners' cognitive and linguistic level.

As research on immersion education has revealed, merely being exposed to, or even engaged in, an activity in the L2 is not sufficient to ensure academic success (Swain \& Johnson, 1997). This, however, this doesn't mean that the solution is to teach 'traditional' grammar by asking students to do endless grammar-based exercises or by breaking language into its component parts of speech. This means affording learners rich, explicit, adjusted and timely interactional scaffolding as students move from the everyday to more formal academic discourse in different school subjects. In content-rich settings this challenge is even greater as teachers' rich and varied linguistic support should be twofold: it should aim to help students acquire both BICS and CALP in the L2. 


\section{The role of teacher talk in guiding learning: Interactional Scaffolding}

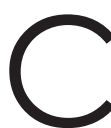

lassroom interaction therefore plays a fundamental role in helping learners appropriate and use academic language efficiently in classrooms. As Lemke (1990: ix) argues, the majority of classroom activities in science classrooms (e.g., solving problems, hypothesizing, questioning, designing experiments) are actually and necessarily linguistic activities as well because they combine two concurrent processes: performing cognitively demanding scientific procedures and communicating complex meanings through language.

This requires engaging learners in interactional processes of 'packing' and 'unpacking' or 'translating' knowledge (Lin, 2016) from academic language to everyday language and back again into academic language. By 'bridging' these two ways of talking about the same topics and explicitly showing similarities and differences between them, teachers develop learners' better comprehension and correct use of subject-specific concepts and content which become increasingly more abstract, de-contextualised and cognitively complex as learners move up the school years (Gibbons, 2003; Lemke, 1990). Yet, although 'bridging' and 'translating' knowledge both seem to be common pedagogic strategies used by many teachers in classroom interaction to make school academic texts accessible to students, they too often do it implicitly without explicitly stating similarities and differences between the two ways of speaking.

Following the principles of the 'learning by doing' pedagogy, nowadays many content-rich classrooms provide students with plenty of experiential, hands-on learning activities during which teachers and students mainly speak in an everyday, informal and highly-contextualised ('hereand-now') manner. However, all too often, immediately after, students are required to produce a written text accounting for their experience. In this reporting phase learners are expected to make a qualitative leap and, as if by magic, deploy high-register academic language in their reports. According to Gibbons (2003), after the hands-on experience, and before moving into a writing stage, one extremely important phase is often missing. This phase is 'an oral reporting stage' where students, guided by the teacher, transform their informal, first-hand experiences and observations into slightly more formal, academic and written-like reports that are understandable also to those who were not directly involved in their experience. Without this intermediate stage, the gap between the two classroom activities (doing and writing) is too big, both linguistically and conceptually. This gap often results in the students' underdeveloped conceptualization of phenomena being studied, and poor written productions.

\section{${ }^{66}$ According to Gibbons (2003), after the hands-on experience, and before moving into a writing stage, one extremely important phase is often missing: an oral reporting stage.}

\subsection{Interactional guiding strategies (Mercer,} 1995)

$D$ ased on educational research in L1 contexts, Neil Mercer (1995) suggested that good teachers use a toolkit of interactional strategies to guide students through the teaching-learning process. Mercer's (1995) classification includes strategies that serve to elicit students' previous knowledge, respond to their contributions and describe important elements of common classroom experiences (Figure 2).

A very common classroom practices is checking and evaluating what students already know and understand about a certain topic. This is usually done through a series of 'display' and closed questions, i.e. the sorts of questions to which there is usually only one acceptable answer which the teacher expects the students to produce. However, using this questioning technique for other pedagogical purposes, such as engaging students in the construction of new knowledge, can have the undesirable effect of shutting down classroom discussion and any potential learning opportunities. This is because display questions tend to elicit short and simple responses from learners, which results in the generation of rather low-quality interaction.

Figure 2. Interactional strategies used by teachers to promote classroom interaction (Mercer, 1995: 34)

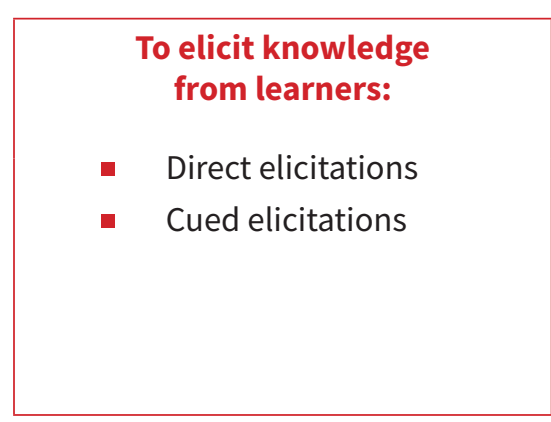

To respond to what learners say:
- $\quad$ Confirmations
- $\quad$ Rejections
- - Elabetitions
$-\quad$ Reformulations

To describe significant aspects of shared experiences:

- 'We' statements

- Literal recaps

- Reconstructive recaps 
Yet, if the pedagogical goal is, for example, to develop students' conceptual understanding of subject-specific knowledge, educational researchers recommend the use of 'referential' and open questions which are meaningful, contextualized and conceptually appropriate for the students' age and which also provide clues as to how they are to be answered. Good questions of this type are those which start with 'why...' or even 'why do you think...' since they aim to promote opinion sharing, critical thinking and reasoning and tend to push learners to produce longer and more complex responses.

Teachers also regularly reply to students' interventions with active and proactive forms of feedback (Lyster, 2007), incorporate what they say into the on-going conversation, and gather their contributions to build more generalized or precise meanings, thereby relating the students' already existing ideas and ways of thinking to new educational frames of meaning. To do this, teachers can simply confirm and/or repeat what students have said or alternatively reformulate/rephrase their contributions or elaborate on them further - or even, if necessary, (respectfully) refute their ideas.

On suitable occasions, teachers also describe significant moments of shared classroom experiences using statements with inclusive pronouns (e.g., 'we', 'us', 'our') and summing up (recapping) what has been done or said thus far to help students realise how different classroom activities they engage in contribute to their learning process or represent common knowledge and a joint understanding. Sometimes, teachers may also employ recaps prior to previewing what is to come in the lesson or directly set up the next activity.

\section{${ }^{66}$ If the pedagogical goal}

is, for example, to develop students' conceptual

understanding of subjectspecific knowledge, educational

researchers recommend the use of 'referential' and open questions which are meaningful, contextualized and conceptually appropriate for the students' age and which also provide clues as to how they are to be answered. Good questions of this type are those which start with 'why...' or even 'why do you think..."'

\subsection{L2 Classroom Interactional Competence (Walsh, 2006)}

$\mathrm{R}$ esearch on classroom interaction in settings where the medium of instruction is often a foreign language for both students and teachers has shown that the role of interactional scaffolding becomes even more vital in such contexts. To better understand how L2 teachers use their interactional skills to enhance teaching and learning in L2 classrooms, Steve Walsh (2006) developed a construct which he labelled Classroom Interactional Competence or CIC. CIC refers to those features of conversations between the teacher and the students (and among students) which produce high quality interaction and create 'space for learning' of the L2. Yet, according to Walsh, 'although CIC is not the sole domain of teachers, it is still very much determined by them' (2006: 130). CIC is therefore:

- The way teachers' appropriate language use enables successful language teaching-learning practices,

- Different strategies used by teachers to engage students in classroom interaction and help them to produce appropriate, meaningful and extended contributions in the L2.

Based on Walsh's (2006) initial classification into three broad categories of those teachers' interactional skills which promote 'space for learning' in L2 classrooms, recent research on teachers' CIC in CLIL contexts has further developed and adapted these categories, taking into account the specificities of CLIL classrooms (e.g., Escobar Urmeneta \& Evnitskaya, 2013; Escobar Urmeneta \& Walsh, 2017). The three CIC categories are as follows.

\section{Category 1: Use of learner-convergent language}

- Use of language which is appropriate both to the pedagogical goals of the moment and to the learners

- Use of interactional strategies which are adjusted to the unfolding agenda of a lesson and facilitate the co-construction of meaning

- Use of interactional modifications and multimodal resources to ensure comprehension

Examples of teachers' interactional scaffolding skills:

- Check students' understanding of what has been done or said thus far using different types of 'comprehension checks'.

- Use linguistic resources such as synonyms, paraphrasing, examples from everyday life as well as non-verbal (gesture, gaze, body, etc.) and material resources (blackboard, visuals, lab instruments, classroom objects, etc.) to explain unknown vocabulary items, complex concepts, new content, etc. 
- When talking, make pauses to let students process input they are receiving.

- Use discourse markers such as 'ok', 'well', 'right', 'now', 'so', etc. to clearly mark the beginning and end of classroom activities and lesson stages.

\section{Category 2: Facilitation of interactional space}

- Use of interactional strategies which provide students with 'space for learning': opportunities to contribute to classroom interaction

Examples of teachers' interactional scaffolding skills:

- Reduce teacher echo: avoid immediate repetition of students' contributions independently of whether they are correct or not.

- Ask good (e.g., 'referential', clear, open) questions to promote critical thinking and reasoning.

- $\quad$ Promote student-initiated questions: good questioning is one of the key elements of effective communication.

- Allow student self-selection: allow to enter the discussion out of turn or without being called on, that is without being nominated or allocated the turn by the teacher.

\section{Category 3: 'Shaping' of learner contributions}

- Use of interactional strategies which involve 'shaping' learner output: helping students to say what they mean by using the most appropriate language

Examples of teachers' interactional scaffolding skills:

- Model academic language use which is linguistically correct and appropriate to the particular discipline.

- Use a wide variety of active and proactive forms of feedback.

- Accept students' contributions and paraphrase them into a more discipline-appropriate language to make them public and available to the rest of the class.

As we can see, the first CIC category helps teachers to create 'space for learning' by making themselves and the curricular content comprehensible for students, that is, by providing all the necessary linguistic support and interactional scaffolding they need. The second CIC category groups those classroom interactional features which aim at creating 'space for learning' by increasing student talking time and reducing teacher talking time. This also allows the tight IRF pattern to be broken by transforming classroom interaction into an I-R-I-R-I-R...-F sequence. Finally, the third CIC category also significantly contributes to opening 'space for learning' by affording students multiple occasions to participate in classroom interaction with longer and more complex turns.
Extract 2 clearly illustrates this:

\section{Extract 2}

1. TEACHER: Ok. STUDENT 1, tell me some physical adaptations about camels.

2. STUDENT 1: ((reads from his notes)) camel has long eyelashes.

3. TEACHER: Very good. Have long eyelashes ((nods)) to keep sand out.

4. STUDENT 1: ((reads)) Can store fat in the hump.

5. TEACHER: Good. They can store fat in the hump. This is a new word I think, "hump", for me is also a new word.

6. STUDENT 2: La gepa

Translation: the hump

7. TEACHER: ((nods)) Yes.

8. STUDENT 1: Yes. ((reads)) Camels' feet are wide.

9. TEACHER: Feet are wide e: why?

10. STUDENT 1: For then they don't (lpoints down at the table with a finger)) go::-

11. STUDENT 2: Down

12. TEACHER: Yes, to walk easily on sand. Very good.

We can see that in line 1 the teacher nominates a specific student to report back the results of his group's collaborative work on the physical adaptations of animals who live in the desert ecosystem. Upon receiving the student's contribution, the teacher first provides a positive feedback to acknowledge that the contribution is correct in terms of the subject-specific content and then expands on it by giving the appropriate scientific justification of this type of adaptation. This pattern is repeated through the extract. However, it is worth mentioning that the teacher occasionally - however very implicitly - also deals with the linguistic aspects. This happens in line 5, when the teacher repairs the student's utterance which lacks the formal subject, a typical mistake made by Spanish-speaking learners of English (including the teacher herself, e.g. line 3), and adds the subject "they". In line 9 the teacher uses a magic question word "why" to elicit a more elaborate answer from the students and in this way to contribute to the development of their cognitive and linguistic competences. This results in a response coconstructed between two students, which, although produced in a rather simple and everyday L2, is still linguistically comprehensible and conceptually correct. This is evidenced in the teacher's explicit acceptance of it as a valid scientific explanation both with an affirmative token and a highly 
positive evaluation/feedback. The teacher yet goes a step further and reshapes the students' contribution into a more academically appropriate statement.

However, according to Walsh (2012), CIC is not a catalogue of pedagogical strategies. Rather, it describes teachers' abilities to make on-line decisions and employ appropriate interactional strategies which allow them to skilfully create 'space for learning' and promote students' participation in classroom interaction, that is, to engage them in the negotiation of meanings and the co-construction of subjectspecific knowledge in the target language.

In content-rich contexts, Escobar Urmeneta and Evnitskaya (2013) suggest that it is necessary to raise CLIL teachers' awareness of the need to interpret and respond appropriately to students' contributions as well as to project them at more advanced levels of development. All this should be done by offering students all the interactional scaffolding needed (albeit temporarily) to guide their actions and learning. Only after having experienced supported participation in meaningful interactions on several occasions will the CLIL student be able to perform independently from the CLIL teacher.

\section{Extract 3}

1. TEACHER: What did the Palaeolithic people do for food? They hunted...

2. STUDENT 1: Dinosaurs

3. TEACHER: NO, not dinosaurs. They hunted wild animals.

4. TEACHER: Ok, next question. Was the Palaeolithic diet healthy? Why?

5. STUDENT 2: Because they didn't eat what we eat, they only had...

6. TEACHER: They only ate meat and fruits they could find in the forests. Correct.

7. TEACHER: Can anybody tell me more reasons?

\section{Shaping learner talk in effective ways}

$\mathrm{R}$ esearch on $\mathrm{CIC}$ in content-rich language learning contexts has shown that even when teachers know how to afford students rich and varied interactional scaffolding to engage them in classroom conversations, students still rarely produce longer contributions, and more accurate ones even less frequently (Dalton-Puffer, 2007). Research has also found that CLIL teachers rarely ask students to modify or extend their utterances, especially if these utterances are acceptable in terms of disciplinary content, nor were teachers found to offer students the linguistic and interactional resources to do so. As for foreign language teachers, it is often the case that real conversational activities are infrequent in the FL classroom, and therefore opportunities to expand basic learners' utterances into more complex ones are also hard to find. Instead, teachers often opt for 'filling the gaps' in learners' contributions rather than giving them the time and resources to make themselves comprehensible. Let's compare Extracts $\mathbf{3}$ and $\mathbf{4}$ below which come from a grade 7 CLIL history class on Palaeolithic people. It is easy to note that the way each teacher uses interactional strategies and orchestrates interaction in their classroom results in different opportunities for learning.

\section{Extract 4}

1. TEACHER: What did the Palaeolithic people do for food? They hunted...

2. STUDENT 1: Dinosaurs

3. TEACHER: Palaeolithic people hunted dinosaurs for food ((writes answer on BB). Really? How extraordinary!

4. TEACHER: Does everyone agree that Palaeolithic people hunted dinosaurs for food? $<\ldots>$

5. TEACHER: Ok, next question. Was the Palaeolithic diet healthy? Why?

6. STUDENT 2: Because they didn't eat what we eat, they only had...

7. TEACHER: Yes. But what did they eat? Do you remember what we read in the text?

8. STUDENT 3: Fruits

9. TEACHER: Exactly! Anything else?

10. STUDENT 2: They also eat meat

11. TEACHER: YES. They only ate meat and fruits which they could find in the forests.

12. TEACHER: Can anybody tell us other reasons why their diet was healthy? 
However, when teachers explicitly work on students' contributions and push them a step further to improve their utterances, they actually expand students' linguistic competence (and the associated conceptual development). They help students progressively produce more appropriate output in terms of subject-specific content as well as construct more precise and complex utterances in the L2. For example, when relevant, teachers can engage students in languagerelated episodes (LRE) by momentarily focusing on form (Ellis, 2006; Nassaji, 2017) and switching class attention to a specific grammatical form or lexical item which students will need to carry out the classroom activity. Teachers can also provide learners with different types of corrective feedback (Lyster, 2007; Lyster \& Ranta, 1997), which can be less or more explicit. Thus, explicit correction allows teachers to clearly indicate that a student's utterance was incorrect and then provide the correct form, but it also constitutes the most direct type of correction. Meanwhile, recasts, which are 'the teacher's reformulation of all or part of a student's utterance, minus the error' (Lyster \& Ranta, 1997: 46), and prompts, which include elicitation, metalinguistic clues, clarification requests and repetition, withhold incorrect forms and instead provide clues to prompt students to self-repair.

To shape or reshape learners' talk, teachers can also paraphrase or reformulate what students say to make it more appropriate linguistically, conceptually or both. In this way both the student who has produced the utterance and the rest of the class receive a 'correct' version of the student's initial contribution. We know, however, that this does not always result in students assimilating the correct form. Therefore, it seems to be better to involve students in the sequences of the negotiation of meaning by, for example, using confirmation checks (e.g., did you say 'he'?), to request confirmation that the student has been understood correctly. Or, by using clarification requests (e.g., pardon? sorry? what do you mean, I don't understand), teachers can ask students to clarify their contributions. In the two examples below (Extracts 5 and 6) from Dalton-Puffer (2007: 121) we see how a CLIL History teacher uses these interactional strategies to push his grade 13 students a step further in their output in the L2.

${ }^{66}$ To shape or reshape learners' talk, teachers can also paraphrase or reformulate what students say to make it more appropriate linguistically, conceptually or both. In this way both the student who has produced the utterance and the rest of the class receive a 'correct' version of the student's initial contribution.

\section{Extract 5}

Clarification request. History, grade 13

1. STUDENT 1: It was a war about information (ah) technology... I would say

2. TEACHER: Mhm ((is writing something on the blackboard)) what do you mean by information technology?

3. STUDENT 1: Info no information and technology

4. TEACHER: Information and

\section{Extract 6 \\ Confirmation check. History, grade 13}

1. TEACHER: Mhm... ja ja ah do I understand Mister Bauer that you you find it most important talking to people who really experienced it all? Talking to eye-witnesses, people who really can tell you what they've gone through?

2. STUDENT 1: I find this very important for me because ah... ah it's a strange feeling if you see your grandmother sitting before you and she starts crying talking about the war. And I can't forget this ever so-

These strategies are usually seen as opening up 'space for learning' and maximising learning potential since they oblige learners to search for a better wording in order to reformulate their contributions, making these more precise, clear and accurate (Dalton-Puffer, Nikula \& Smit, 2010).

A comparative study by Llinares and Lyster (2014) on corrective feedback in primary school immersion classrooms in Canada and Japan and primary CLIL classrooms in Spain shows that in all three educational contexts teachers tended to use recasts most frequently, followed by prompts and only then explicit correction. According to the authors, these findings 'might be considered well-tuned to the objectives of CLIL and immersion programmes' because 'recasts serve to: (1) maintain the flow of communication; (2) keep students' attention focused on content; and (3) enable learners to participate in interaction that requires linguistic abilities exceeding their current developmental level' (Llinares \& Lyster, 2014: 188). However, despite similar patterns of corrective feedback, the way primary teachers in the study shaped the instructional context and its communicative orientation in accordance with their beliefs and experiences resulted in different sorts of learner uptake, that is, the ways learners responded to the teachers' move containing corrective feedback.

According to Llinares and Lyster (2014), classroom observations detected that, for example, in Japanese Immersion classrooms, choral repetition, individual 
repetition and reading aloud were frequently used to promote speaking skills. The fact that Japanese Immersion students repeated their teachers' recasts much more often might explain a high degree of learner uptake in this context in comparison to French Immersion and CLIL classrooms. Meanwhile, in French Immersion classrooms, students were observed to respond more to prompts than to recasts, which might be due to their teachers' preference to use prompts to focus on language issues. Finally, in CLIL classrooms, primary teachers seemed to be more conscious of the language aspect since they used more recasts. Such findings in CLIL contexts might be due to the fact that CLIL primary teachers are often EFL teachers as well as non-native speakers of English, as opposed to native teachers in the other two educational contexts examined.

By not always and immediately accepting a student's first contribution and not reformulating it themselves, teachers encourage students to be more precise in what they are saying or to develop their ideas more fully. This often results in learners producing longer and more complex utterances in the L2, which contributes to their language development. Yet, especially in content-rich contexts with students who have a low level of the L2, teachers might need to provide students with necessary language support to enable them to continue and expand on their contributions, this support being either specific terminology, grammatical structures or general academic language items required by the disciplinary content being talked about or the nature of the task to be carried out (Gibbons, 2014). With time and the improvement of students' competence and linguistic repertoire in the L2, this temporary scaffolding may no longer be necessary and can be gradually reduced. In her description of a primary school content-rich classroom, Gibbons (2003) shows a science teacher can effectively use rich and varied interactional scaffolding to guide and support young L2 learners in their journey from everyday language to more abstract and specialised academic language when learning about magnets.

Wait time has been found to be another important factor for opening up learning opportunities and potentially leading to students' cognitive and linguistic development. Research on classroom interaction has shown that, on average, after asking a question a teacher waits less than one second for a student to answer (e.g., Nunan, 1991). Just one second to process the teacher's question and respond, in a foreign language! No wonder teachers so often fail to get any response from students! Giving students a longer wait time, of 4-5 seconds or more, not only increase the chances of getting more students to contribute but can also trigger more meaningful and elaborate interventions. Extending wait time is therefore an effective elicitation technique because increasing both the number of pauses and their length after asking a question affords students the chance to think, formulate and construct a response which is often longer and more complex than one which is produced hastily under pressure.

One of the big issues in CLIL regards code-switching,

\section{${ }^{66}$ Giving students a longer wait time, of 4-5 seconds or more, not only increase the chances of getting more students to contribute but can also trigger more meaningful and elaborate interventions.'}

i.e. whether the use of the L1 should be allowed in the classroom or not. A generally accepted principle in CLIL settings is that the use of the L2 should be actively promoted for all purposes, that is, teaching, learning, class management, etc. (Dalton-Puffer, Nikula \& Smit, 2010). However, there are situations when teachers may resort to the L1 when they feel there is a clear need to do so. This may be the case, for instance, when the teacher needs to discuss with the student some delicate or personal issue, when the importance to establish a close human connection with the student or give emotional support temporarily prevails over pedagogical goals.

However, especially when students have a low-level competence in the L2, using students' L1 for general classroom functions and interactions can be beneficial for learning (see e.g., chapter 5 in Lin, 2016). Clearly, if students' linguistic-discursive repertoire in the target language is very limited, their capacity to produce contentrelated knowledge in the L2 is likely to be very low as well. In such cases, allowing students to code-switch and resort to their L1 can ensure that they are not excluded from active participation in classroom interaction and enable them to contribute meaningfully to the joint process of knowledge construction. The teacher's role is then to collect students' interventions in the L1 and return them appropriately in the L2 to the whole class.

\section{Face-Saving repair strategies, positive self-image and emotional support}

$\mathrm{F}$ inally, another - yet no less important - role of the teacher is to create a safe environment where students develop a positive self-image through their interactions, and to provide emotional support in the classroom.

One common teacher practice in classroom interaction is error correction or repair, which can either address problems of linguistic form or problems related to disciplinary/ conceptual inappropriateness or both. Repair can be direct or indirect and often depends on the way teachers identify problems in interaction as well as on the particular type of problem. When teachers signal a problem in students' utterances by correcting it, they use what some researchers call 'other-initiated repair'. However, it can sometimes happen that after producing a faulty utterance the student 
him or herself becomes aware that there is an error and attempts to self-correct without any signal from the teacher. In this case, we can say that the student has used a 'selfinitiated repair' strategy.

Social-interactionist researchers, who criticise a so-called 'deficit' approach to language learning (Cook, 1999), opted for the term 'repair' instead of 'correction' because it better describes what happens in everyday conversations, where participants do not usually correct each other's utterances. The term 'repair' focuses on what the learner can do with the language, whereas the term 'correction' seems to focus on what the learner still cannot do in the L2 or does incorrectly. Thus, the concept of 'repair' is more in line with empowering approaches to language learning.

Both self-initiated and other-initiated repair can be very delicate actions because they involve face-work. Facework means dealing with one's public self-image, i.e. the way people see themselves in relation to other people. On the one hand, we often seek approval or want to be liked, acknowledged and appreciated by others. On the other hand, we may sometimes need to be autonomous, free to act the way we want and not be imposed upon. When interacting with other people, we do things using language such as advise, promise, apologize, request, invite, repair, etc. All these verbal actions constitute a face threat since they can impose on other persons' face as well as on their needs.

Research on face-work argues that face threat is inevitable in any interaction, so participants in interaction (interactants) usually try to maintain each other's face and avoid possible face-threats during day-to-day exchanges. With this aim, they use face-saving strategies, which can be of several types. The first type, positive politeness or 'solidarity strategies', highlights involvement, closeness, friendship, etc. However, expressing closeness with other people too directly can sometimes be considered offensive, which is why people often prefer negative politeness or 'deference strategies', which help them show respect for their interlocutor's time or concerns, avoid imposition or highlight distance between the interactants. Sometimes, when the risk of face-threat is too great, interactants may seek to avoid it by using linguistic resources which can help them mitigate, that is decrease, the degree of risk and approach the problematic or delicate issue indirectly. In such cases, mitigation linguistic strategies such as hedging, hinting, making indirect suggestions or evenly disagreeing indirectly can be of great help.

In classroom settings, repair can require considerable delicacy on the part of the teacher. Providing corrective feedback in insensitive ways, such as repairing students' utterances too directly, too frequently or at an inappropriate moment, can damage students' self-image and lower their self-esteem. To protect students' self-image, it is therefore important to keep repair practices constantly in line with the pedagogical purpose of the lesson. This is not to say that repair should be completely avoided altogether. There are instances when repair can help students to express their ideas or knowledge more effectively or precisely, thus favouring their learning. This can be the case, for example, when students are trying

\section{${ }^{66}$ In classroom settings, repair can require considerable delicacy on the part of the teacher. Providing corrective feedback in insensitive ways, such as repairing students' utterances too directly, too frequently or at an inappropriate moment, can damage students' self-image, and lower their self-esteem.'}

to define a certain concept or explain some procedure where linguistic and conceptual precision is important. Yet, there are other moments when repair would get in the way by interrupting the flow of interaction or student talk and thus take away possible learning opportunities.

There are other ways to attend to students' self-image and provide emotional support. One is to give positive feedback in a variety of ways to encourage students to participate more actively in interaction or make another attempt to elaborate on their contributions, etc. Praising students for their achievements, both academic and linguistic, using both verbal and non-verbal resources such as gestures, gazes, smiles, etc. also helps create a positive environment in the classroom and boosts students' self-image. Finally, a frequent use of 'we' statements when talking about shared past and future classroom and learning experiences contributes to building a sense of community and a positive atmosphere in the classroom.

\section{To conclude}

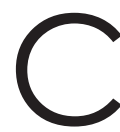
ontentand/or language learning is not the unavoidable result of the implementation of stimulating learning tasks and attractive teaching materials aimed at fostering the development of students' linguistic and cognitive competences. Yet, we should bear in mind that the same tasks and the same teaching materials can result in very productive or very unproductive lessons depending on the way the teacher organises classroom interaction. Thus, on the one hand, by actively engaging students in meaningful, conceptually and linguistically challenging activities and high quality classroom conversations in content-rich contexts, teachers can efficiently guide students in better understanding of subject-specific content and promote the development of their communicative competence in a foreign language as well as of the integrated learning of content and language. On the other hand, the teacher's savoir-faire to provide emotional support in the classroom and to create a safe environment where students can develop a positive selfimage through their interactions both with the teacher and the peers is also likely to enhance the learners' participation in the co-construction of academic knowledge in the L2. 


\section{References}

Cook, V. (1999). Going Beyond the Native Speaker in Language Teaching. TESOL Quarterly 33/2: 185-210.

Cummins, J. (1991). Conversational and academic language proficiency in bilingual contexts. In J. H. Hulstijn \& J. F. Matter (Eds.), Reading in two languages (pp. 75-89). Amsterdam: AILA.

Dalton-Puffer, C. (2007). Discourse in CLIL classrooms. Amsterdam: John Benjamins.

Dalton-Puffer, C., Nikula, T. \& Smit, U. (eds.) (2010). Language Use and Language Learning in CLIL Classrooms. Amsterdam: John Benjamins.

Ellis, R. (2006). Researching the effects of Form-Focused Instruction on Language Acquisition. AILA Review 19: $18-41$.

Escobar Urmeneta, C. (2016). Aprendizaje integrado de contenidos y lengua. In D. Masats \& L. Nussbaum (eds.), Enseñanza y aprendizaje de las lenguas extranjeras en educación secundaria obligatoria (pp.85-111). Madrid: Síntesis.

Escobar Urmeneta, C. \& Evnitskaya, N. (2013). Affording Students Opportunities for the Integrated Learning of Content and Language. A Contrastive Study on Classroom Interactional Strategies Deployed by Two CLIL Teachers. In J. Arnau (ed.), Reviving Catalan at School: Challenges and Instructional Approaches (pp.158-182). Bristol: Multilingual Matters \& Institut d'Estudis Catalans.

Escobar Urmeneta, C. \& Walsh, S. (2017). Classroom interactional competence in content and language integrated learning. In: A. Llinares \& T. Morton (Eds.), Applied Linguistics Perspectives on CLIL (pp.183-200). Amsterdam: John Benjamins.

Gibbons, P. (2003). Mediating Language Learning: Teacher Interactions with ESL Students in a Content-Based Classroom. TESOL QUARTERLY 37 (2): 247-273.

Gibbons, P. (2014). Scaffolding Language, Scaffolding Learning: Teaching Second Language Learners in the Mainstream Classroom, 2nd edition. Portsmouth: Heinemann.

Lemke, J.L. (1990). Talking science: language, learning and values. Norwood, NJ: Ablex.

Lin, A.M.Y. (2016). Language Across the Curriculum \& CLIL in English as an Additional Language (EAL) Contexts: Theory and Practice. Singapore: Springer Science+Business Media Singapore.

Lyster, R. (2007). Learning and Teaching Languages through Content: A Counterbalanced Approach. London: Continuum.
Lyster, R. \& Ranta, L. (1997). Corrective feedback and learner uptake: negotiation of form in communicative classrooms. Studies in Second Language Acquisition 19: 37-76.

Llinares, A. \& Lyster, R. (2014). The influence of context on patterns of corrective feedback and learner uptake: a comparison of CLIL and immersion classrooms. The Language Learning Journal 42/2: 181-194.

Mehan, H. (1979). Learning Lessons: Social Organization in the Classroom. Cambridge, MA: Harvard University Press.

Mercer, N. (1995). The Guided Construction of Knowledge. Clevedon: Multilingual Matters.

Mercer, N. (2000). Words and minds: How we use language to think together. London: Psychology Press.

Mercer, N. (2004). Sociocultural discourse analysis: analysing classroom talk as a social mode of thinking. Journal of Applied Linguistics, 1(2):137-168.

Nassaji, H. (2017). Grammar Acquisition. In Lowen, S. \& Sato, M. (eds.), The Routledge Handbook of Instructed Second Language Acquisition. New York/London: Routledge Taylor \& Francis Group.

Nikula, T., Dalton-Puffer, C. \& Llinares, A. (2013). CLIL classroom discourse. Journal of Immersion and ContentBased Language Education, 1 (1): 70-100.

Nunan, D. (1991) Language Teaching Methodology, Hemel Hempstead: Prentice-Hall.

Sinclair, J. \& Coulthard, M. (1975). Towards an Analysis of Discourse. Oxford: Oxford University Press.

Swain, M. \& Johnson, K. (1997). Immersion education: A category within bilingual education. In K. Johnson and M. Swain (eds.), Immersion Education: International Perspectives, pp. 1-16. Cambridge, UK: Cambridge University Press.

van Lier, L. (2008). Agency in the classroom. In J.P. Lantolf and M.E. Poehner (eds.), Sociocultural theory and the teaching of second languages, pp. 163-186. London: Equinox.

Walsh, S. (2006). Investigating Classroom Discourse. London: Routledge.

Walsh, S. (2012). Conceptualising Classroom Interactional Competence. Novitas-ROYAL (Research on Youth and Language) 6 (1): 1-14. 